\title{
Klasyk nieortodoksyjny. Estetyka książki w twórczości Andrzeja Heidricha
}

Grafika użytkowa to dział grafiki służący konkretnym celom. Quentin Newark, projektant i autor podręcznika grafiki użytkowej, opisuje ją słowami: „To najbardziej uniwersalna dziedzina sztuki. Tłumaczy, zdobi, identyfikuje: wywiera wpływ na otaczający nas świat". Jest to bowiem dyscyplina o bardzo szerokim zakresie, a do jej zadań należy: projektowanie książek, ilustracji, plakatów, druków akcydensowych, znaczków pocztowych, banknotów i tym podobnych. Termin ten powstał w drugiej połowie XIX wieku, gdy nastąpiło odrodzenie ambitnej grafiki warsztatowej. Od tego czasu aż do dziś powstało wiele interesujących dzieł sztuki użytkowej.

Z perspektywy rozwoju tej dziedziny dość nietypowy był okres PRL: zjednej strony sprzyjano jej postępowi — kwitł plakat, prężnie rozwijała się Polska Szkoła Ilustracji, dbano, by artyści projektowali druki użytku publicznego, to jest znaczki pocztowe czy pieniądze, z drugiej jednak — projektowanie książki było często obszarem drugiej kategorii, znacznie mniej istotnym od pozostałych dziedzin grafiki użytkowej. Typografia nie rozwijała się u nas tak prężnie jak na Zachodzie, brakowało odpowiednich kierunków akademickich czy fachowych publikacji poświęconych sztuce projektowania książki. Jakość graficzna wydawanych książek pozostawiała wiele do życzenia. Niejednokrotnie uzależnione to było także od słabości przemysłu poligraficznego (przestarzałe maszyny, brak odpowiednich krojów pisma, niedopuszczanie grafika do drukarni i tym podobne).

W celu podniesienia jakości typograficznej rodzimych publikacji w 1958 roku Polskie Towarzystwo Wydawców Książek powołało Konkurs na Najlepiej Wydaną Książkę Roku (od 1981 roku pod nazwą Konkurs PTWK Najpiękniejsze Książki Roku). Jest to najważniejszy w Polsce konkurs, w którym specjaliści w dziedzinie projektowania edycji oceniają ich szaty graficzne. Kryteria, jakimi początkowo kie-

${ }^{1}$ Q. Newark, Design i grafika dzisiaj. Podręcznik grafiki użytkowej, Warszawa 2006, s. 6. 
rowało się jury, przyznając nagrody, to: koncepcja wydawnicza, związek formy z treścią, projekty graficzne, wybór czcionki i układu, skład, łamanie, jakość reprodukcji, druk, wykonanie introligatorskie oraz wybór papieru i innych potrzebnych surowców ${ }^{2}$. Natomiast obecny regulamin (zatwierdzony w 2015 roku) wskazuje na pięć przedmiotów oceny książek: koncepcję wydawniczą, opracowanie graficzne, poziom artystyczny ilustracji, opracowanie typograficzne i jakość wykonania technicznego ${ }^{3}$.

Mimo wskazanych trudności w Polsce działali pasjonaci, którzy specjalizowali się w projektach książkowych. Jednym z mistrzów docenianych przez PTWK i niejednokrotnie nagradzanych w konkursach jest bez wątpienia Andrzej Heidrich - wybitny polski grafik urodzony w 1928 roku, znany głównie jako twórca banknotów Narodowego Banku Polskiego. Z tej perspektywy ukazano jego dorobek chociażby na wystawie „Andrzej Heidrich — malarz banknotów”, która została zorganizowana przez Muzeum Miejskie Wrocławia i NBP w dniach od 23 stycznia do 8 maja 2016 roku. W Pałacu Królewskim można było podziwiać kilkaset jego prac, przede wszystkim banknoty i ich projekty (również te, które nie weszły do obiegu), a także medale, odznaczenia, znaczki i kartki pocztowe, ilustracje oraz — w niewielkim zakresie — książki.

Osiągnięcia Heidricha w dziedzinie typografii książkowej są niesłusznie pomijane. Dlatego celem niniejszego artykułu jest przybliżenie tego aspektu jego twórczości, przypomnienie o znakomitym dorobku oraz ukazanie cech charakteryzujących go jako wybitnego projektanta książek.

\section{Charakterystyka epoki}

Po II wojnie światowej w Polsce nastąpił zauważalny rozkwit grafiki użytkowej. Bez wątpienia, najbardziej spektakularny sukces w tej dziedzinie odniosła Polska Szkoła Ilustracji. Za jej najważniejszego przedstawiciela uważa się Jana Marcina Szancera (1902-1973) — grafika specjalizującego się w książkach dziecięcych i młodzieżowych, który jako profesor warszawskiej Akademii Sztuk Pięknych był również nauczycielem młodszych pokoleń grafików, w tym Andrzeja Heidricha ${ }^{4}$. Do grupy artystów książki tworzących w Polsce Ludowej należy zaliczyć również takie osoby, jak: Olga Siemaszko, Bohdan Zieleniec, Bohdan Butenko, Janusz Grabiański, Jan Młodożeniec, Janusz Stanny czy Józef Wilkoń. W omawianym okresie rodzimi projektanci zdobywali duże uznanie za granicą. Pierwszym znaczącym sukcesem był udział w III Międzynarodowej Wystawie

${ }^{2}$ Cztery Konkursy na Najlepiej Wydaną Książkę w latach 1957-1961, oprac. R. Tomaszewski, Warszawa 1964, s. 10.

${ }^{3}$ Regulamin konkursu Polskiego Towarzystwa Wydawców Książek ,,Najpiękniejsze Książki Roku”, http://www.ptwk.pl/images/pdf/2017/Regulamin_NKR.pdf [dostęp: 27.06.2017].

${ }^{4}$ Andrzej Heidrich - twórca polskich banknotów, Warszawa 2011, http://www.nbp.pl/AndrzejHeidrich/e-book/files/assets/downloads/files/AndrzejHeidrich.pdf [dostęp: 23.04 2016]. 
Książki w Lipsku w 1959 roku, z której Polacy przywieźli aż trzynaście medali (w tym brązowy Heidricha) . $^{5}$

W okresie powojennym wykształciło się również pojęcie Polskiej Szkoły Plakatu. Za jej twórcę uważany jest Henryk Tomaszewski, zdobywca pięciu pierwszych nagród na Międzynarodowym Festiwalu Plakatu Filmowego w Wiedniu w 1948 roku, którego wyczyn zaowocował zainteresowaniem polską sztuką użytkową poza granicami kraju ${ }^{6}$. Polscy plakaciści (oprócz Tomaszewskiego na przykład Tadeusz Konwicki, Waldemar Świerzy, Maciej Urbaniec) niejednokrotnie przenosili swoje pomysły na okładki książkowe, traktując je jako małe plakaty?

Niestety, ta złota era polskiej grafiki w dużo mniejszym stopniu dotyczyła typografii, o czym świadczą chociażby definicje pochodzące z tamtego okresu, traktujące ją jako technikę druku wypukłego, marginalizując takie aspekty, jak projektowanie układu graficznego publikacji czy tworzenie pism drukarskich oraz zupełnie pomijając jej funkcję komunikacyjną ${ }^{8}$. Mimo zaniedbywania tej dziedziny w okresie PRL funkcjonowało wtedy kilku mistrzów specjalizujących się w sztuce składu, wśród których można wyróżnić Leona Urbańskiego czy Andrzeja Heidricha. Powstało wtedy wiele doskonałych edycji, które współzawodniczyły z sobą w Konkursie na Najlepiej Wydaną Książkę Roku.

Niezbyt dobrze wyglądała również sytuacja typografii w znaczeniu projektowania pism. Co prawda w 1960 roku Zygfryd Gardzielewski stworzył Antykwę Toruńską (dwuelementowy font szeryfowy), lecz w latach sześćdziesiątych razem z Antykwą Półtawskiego były one jedynymi krojami o pełnym garniturze, stworzonymi w Polsce na przestrzeni dekad ${ }^{9}$. Sytuację starał się poprawić Roman Tomaszewski, próbując odbudować przemysł poligraficzny w Szczecinie i Wrocławiu oraz wydając od 1966 roku czasopismo „Litera”, w całości poświęcone tematyce typograficznej ${ }^{10}$. W roku 1968 również z jego inicjatywy powstał w Warszawie Ośrodek Pism Drukarskich, w ramach którego powstały takie kroje, jak Kurier Małgorzaty Budyty czy Bona Andrzeja Heidricha ${ }^{11}$.

Ze względu na dużą liczbę działających wtedy twórców trudno jednoznacznie określić styl polskiej grafiki okresu PRL. Jednak wśród tej różnorodności nurtów i technik, oryginalnych pomysłów oraz nieszablonowych rozwiązań pojawiały się pewne cechy wspólne dla wielu projektantów. Pokolenie Heidricha starało się przede wszystkim odchodzić od bogactwa kolorów i szczegółowości na rzecz prostoty, skró-

${ }^{5}$ A. Wincencjusz-Patyna, U źródeł światowych sukcesów Polskiej Szkoty Ilustracji, „Quart. Kwartalnik Instytutu Historii Sztuki Uniwersytetu Wrocławskiego” 2009, nr 1, s. 18.

${ }^{6}$ Ibidem, s. 5.

7 J. Mrowczyk, M. Warda, PGR: Projektowanie graficzne w Polsce, Kraków 2010, s. 20.

${ }^{8}$ E. Repucho, Od sztuki pięknego składu do narzędzia komunikacji wizualnej. Przemiany pojęcia typografii na przestrzeni XX i początków XXI wieku, „Acta Poligraphica” 2016, nr 8, s. 90.

9 A. Szydłowska, M. Misiak, Paneuropa, Kometa, Hel: szkice z historii projektowania liter w Polsce, Kraków 2015, s. 88.

${ }^{10}$ Ibidem, s. 92-93.

11 Ibidem, s. 102-105. 
tu plastycznego, aluzyjności i metaforyki ${ }^{12}$. Coraz częściej w poszukiwaniu nowych środków wyrazu dokonywano interesujących eksperymentów, polegających na przykład na zaskakującym wkomponowywaniu tekstu w grafikę lub odwrotnie ${ }^{13}$. Popularną tendencją było czerpanie inspiracji ze sztuki ludowej — przetwarzanie jej motywów i wykorzystywanie charakterystycznych dla niej zestawień kolorystycznych ${ }^{14}$.

Pomimo panujących wtedy ograniczeń w wielu sferach życia społecznego twórcy grafiki użytkowej mieli dobre warunki do swobodnego rozwoju. Wynikało to z nastawienia władzy, która postrzegała ten rodzaj sztuki jako sprzymierzeńca systemu w upowszechnianiu kultury, nie obawiając się przy tym nacechowania ideologicznego, zwłaszcza w książkach dla dzieci ${ }^{15}$. Popularność grafiki użytkowej wśród twórców podyktowana była również względami ekonomicznymi. Objęte mecenatem państwowym projektowanie ilustracji, plakatów, znaczków, kart pocztowych czy druków ulotnych zapewniało większy i bardziej stały dochód niż na przykład malarstwo sztalugowe ${ }^{16}$. O wynagrodzeniach decydował ustawowy, a więc jednakowy dla wszystkich cennik, uzależniający stawkę między innymi od formatu pracy i nakładu ${ }^{17}$.

Możliwości grafików po II wojnie światowej ograniczał zły stan polskiego drukarstwa, które podlegało gospodarce centralnie planowanej. Przemysł ten borykał się z problemami kadrowymi — w drukarniach brakowało wykwalifikowanych pracowników ${ }^{18}$. Wpływ czynników partyjnych powodował, że podejmowano nietrafione decyzje, których skutkiem był zbyt powolny rozwój papiernictwa w stosunku do potrzeb i rosnących nakładów ${ }^{19}$. Brakowało odpowiedniego papieru, jego jakość była niewystarczająca, a formaty nieprzystosowane do maszyn drukarskich ${ }^{20}$. Podobna sytuacja dotyczyła materiałów introligatorskich, które nie spełniały odpowiednich norm, oraz złej jakości farb produkowanych z innych surowców niż na Zachodzie i wykorzystywanych dowolnie, bez względu na rodzaj druku czy papieru ${ }^{21}$. Inny problem stanowiły przestarzałe maszyny i niedostateczne wyposażenie drukarni w materiał zecerski - wybór czcionek był ubogi, a wiele zestawów wybrakowanych ${ }^{22}$. Z powodu tych ograniczeń projektanci

12 E. Skierkowska, Współczesna ilustracja książki, Wrocław 1969, s. 72.

13 Ibidem, s. 64-65.

${ }^{14}$ A. Wincencjusz-Patyna, op. cit., s. 26.

15 Ibidem, s. 5.

16 Ibidem, s. 18.

${ }^{17}$ W. Fangor et al., Jak ktoś mógł na to pozwolić! Z twórcami polskiej szkoły grafiki rozmawia Janusz Górski, Warszawa 2011, s. 56.

18 A. Chamera-Nowak, Problemy złej jakości wykonania książek w latach pięćdziesiatych XX wieku w Polsce: stalinowskie diagnozy, rzeczywiste przyczyny, „Z Badań nad Książką i Księgozbiorami Historycznymi” 2013, t. 7-8, s. 120.

${ }_{19}$ M. Szymczyk, Polski przemyst papierniczy 1945-1989, Duszniki Zdrój 2007, s. 103.

20 A. Chamera-Nowak, op. cit., s. 120.

${ }^{21}$ Ibidem, s. 129.

22 Ibidem, s. 117-118. 
niejednokrotnie musieli zmieniać koncepcje swoich dzieł i dostosowywać je do panujących warunków technicznych ${ }^{23}$.

Sytuacja nie poprawiała się w latach 1970-1980. Do Polski sprowadzono nowe, bezużyteczne maszyny wymagające wykwalifikowanych drukarzy i niedostępnego wówczas papieru, co przełożyło się na obniżenie jakości publikacji ${ }^{24}$. Pod koniec lat siedemdziesiątych do zahamowania rozwoju sztuki użytkowej przyczynił się również brak młodych talentów. Ponadto sytuacja ekonomiczna państwa nie pozwalała na realizowanie dotychczasowej polityki kulturalnej. Działalność wydawnicza w Polsce zaczęła upadać, co wpłynęło na słabnące zapotrzebowanie na specjalistów od projektowania książek ${ }^{25}$. Problem złej jakości publikacji nie został rozwiązany aż do zmian w roku $1989^{26}$. Dawna świetność polskiej grafiki użytkowej nie została przywrócona także w pierwszych latach po transformacji ustrojowej. Projektanci musieli mierzyć się z takimi problemami, jak drapieżny marketing, niska kultura wizualna i brak świadomości roli grafiki w nowoczesnym społeczeństwie ${ }^{27}$.

\section{Andrzej Heidrich — życie i twórczość}

Andrzej Heidrich urodził się 6 listopada 1928 roku w Warszawie. Pochodzi $\mathrm{z}$ rodziny o silnie zakorzenionych tradycjach patriotycznych. Jego ojciec Adolf Heidrich (1899-1983) był wybitnym ekonomistą, harcmistrzem Rzeczypospolitej i działaczem niepodległościowym, natomiast dziadek Aleksander Osiński (1870-1956) pełnił funkcje senatora II Rzeczypospolitej, generała dywizji Wojska Polskiego, a także prezesa Polskiego Czerwonego Krzyża ${ }^{28}$.

Kształcenie w kierunku sztuki książki rozpoczął w graficznej szkole zawodowej przy ulicy Konwiktorskiej, gdzie nauczycielem był między innymi Adam Półtawski, twórca słynnej polskiej antykwy. Młody Heidrich pomagał mu niekiedy po lekcjach w pracach nad jednoelementowym krojem pisma, którego dalsze losy są niestety nieznane ${ }^{29}$. Po II wojnie światowej uczęszczał do Liceum Sztuk Plastycznych, gdzie w jednej klasie spotkał się z takimi znanymi później osobistościami, jak graficy Jan Lebenstein i Leon Urbański ${ }^{30}$ czy scenograf i aktorka Krystyna

${ }^{23}$ A. Wincencjusz-Patyna, op. cit., s. 18.

${ }^{24}$ P. Sitkiewicz, Jak ktoś mógł na to pozwolić! Z twórcami polskiej szkoły grafiki rozmawia Janusz Górski, red. P. Sitkiewicz, Warszawa 2011, s. 59.

25 A. Wincencjusz-Patyna, op. cit., s. 28.

26 A. Chamera-Nowak, op. cit., s. 130.

27 J. Mrowczyk, M. Warda, op. cit., s. 11.

28 Andrzej Heidrich. Malarz polskich banknotów, http://www.muzeum.miejskie.wroclaw.pl/ CMS/muzeum_historyczne/heidrich.html [dostęp: 23.04.2016].

29 A. Frankowski, M. Frankowska, Dyskretna Perfekcja, ,2+3D” 2011, nr 2, s. 46.

30 A. Heidrich, Sztuka proporcji, [w:] Lucem dabit atra fuligo. Światto dała czarna sadza. Leon Urbański (1926-1998), Warszawa 2007, s. 11. 
Zachwatowicz ${ }^{31}$. W 1948 roku rozpoczął studia na Wydziale Grafiki warszawskiej Akademii Sztuk Pięknych. Dyplom, którego tematem były ilustracje do komedii Moliera Świętoszek, uzyskał w 1954 roku u profesora Jana Marcina Szancera.

Heidrich jest autorem wielu doskonałych projektów książkowych. Już w czasie studiów związał się ze Spółdzielnią Wydawniczą „Czytelnik”, w której w 1961 roku objął funkcję kierownika artystycznego, a trzynaście lat później naczelnego grafika. Projektował dla niej ilustracje, okładki bądź całe publikacje, albowiem jego postawę charakteryzuje myślenie o książce jako nierozerwalnej całości. Współpracował także z innymi wydawnictwami, takimi jak Nasza Księgarnia czy Państwowy Instytut Wydawniczy. W sumie opracował graficznie ponad sześćset książek ${ }^{32}$. Chociaż większość z nich przypadła na okres PRL, projektował także po transformacji ustrojowej.

Chcąc uniknąć powtarzalności, Heidrich podejmował różne wyzwania; brał na warsztat teksty należące do wszystkich rodzajów literackich — epiki, liryki i dramatu. Każdy z nich wymaga odmiennego ukształtowania edytorskiego, a więc zupełnie innego podejścia projektanta. Chętnie opracowywał również albumy — w swoim dorobku ma ich blisko czterdzieści. Książki zaprojektowane przez Heidricha wielokrotnie zachwycały krytyków. Najlepszym na to dowodem jest Konkurs PTWK Najpiękniejsze Książki Roku, w którym jego prace zdobyły jedenaście nagród (nie licząc wyróżnień). Znajdziemy tu klasykę literatury polskiej, a także tłumaczenia dzieł zagranicznych autorów. Już jako znany i ceniony grafik sam zasiadał w jury tego konkursu.

Pomimo tak okazałego dorobku „książkowego” Heidrich postrzegany jest głównie jako twórca polskich banknotów. Świadczą o tym chociażby artykuły i wywiady z grafikiem, które w większości przypadków skupiają się na temacie papierowych pieniędzy, traktując książki w sposób marginalny. Przygodę z Narodowym Bankiem Polskim rozpoczął w 1960 roku od wyróżnienia w konkursie na banknot o nominale $1000 \mathrm{zt}^{33}$. Jednak stała współpraca rozpoczęła się od następnej edycji konkursu. W połowie lat sześćdziesiątych NBP zwrócił się z prośbą do Heidricha o zaprojektowanie banknotów przedstawiających polskie miasta, ale ostatecznie zadecydowano o zmianie tematyki na wybitnych Polaków. W ramach pracy pod koniec lat sześćdziesiątych Heidrich został oddelegowany przez NBP do Mediolanu na szkolenia z zakresu metod projektowania i najnowszych technik zabezpieczen ${ }^{34}$. Jego pierwszy banknot (500 zł z wizerunkiem Tadeusza Kościuszki) został wprowadzony do obiegu w 1975 roku $^{35}$. Polska Wytwórnia Papierów Wartościowych zrealizowała dwie serie jego banknotów: „Wielcy Polacy” (w obiegu do 1996 roku) oraz „Władcy polscy”, funkcjonującą do dziś. Dzięki temu jego prace

\footnotetext{
31 A. Frankowski, M. Frankowska, op. cit., s. 46, 53.

32 Ibidem, s. 46.

33 Ibidem, s. 50.

34 Ibidem, s. 50.

${ }^{35}$ Andrzej Heidrich - twórca polskich banknotów...
} 
zna tak naprawdę każdy. Można powiedzieć, że nie ma w Polsce drugiego grafika, którego prace byłyby rozpowszechnione w społeczeństwie na porównywalną skalę. Współpraca Hedricha z NBP miała swój dalszy ciąg, był bowiem odpowiedzialny za tworzenie banknotów okazjonalnych oraz projekt nowego banknotu o nominale $500 \mathrm{zł} \mathrm{z} \mathrm{portretem} \mathrm{Jana} \mathrm{III} \mathrm{Sobieskiego,} \mathrm{który} \mathrm{wprowadzono} \mathrm{do} \mathrm{obiegu} \mathrm{w} 2017$ roku.

Oprócz banknotów Heidrich jest również autorem wielu znaczków pocztowych, herbów, projektów polskich paszportów i dowodów osobistych, patentów oficerskich, orderów, orzełków wojskowych, odznak policyjnych, pieczęci Kancelarii Prezydenta, a nawet logo Sejmu RP. Po obaleniu komunizmu pracował także nad obecnym kształtem godła polskiego ${ }^{36}$. Zainteresowanie projektowaniem dokumentów, odznaczeń i symboli państwowych może wywodzić się z działalności patriotycznej jego ojca i dziadka. Nie bez znaczenia jest jego fascynacja postacią Józefa Piłsudskiego, którego spotkał osobiście jako dziecko, co głęboko zapadło mu w pamięć. Podczas spaceru sześcioletni wówczas Heidrich dostrzegł idącego z naprzeciwka marszałka i zasalutował mu, na co ten odpowiedział przyjaznym gestem — podszedł do chłopca i pogłaskał go po głowie ${ }^{37}$.

Heidrich to również specjalista od tworzenia ekslibrisów. Wielokrotnie miały one charakter heraldyczny i alegoryczny ${ }^{38}$. Tworzył je między innymi dla Jarosława Iwaszkiewicza, Karla Dedeciusa czy Juliusza Englerta. W 1979 roku odniósł w tej dziedzinie znaczący sukces, zdobywając I miejsce w prestiżowym konkursie na ekslibris ku pamięci Tadeusza Przypkowskiego - pochodzącego z Jędrzejowa historyka sztuki, bibliofila i grafika znanego z projektowania zegarów słonecznych ${ }^{39}$.

Jako wszechstronny twórca, Heidrich zajmował się także projektowaniem liter. Jego najważniejszym osiągnięciem w tej dziedzinie była Bona z 1971 roku — akcydensowy, lekko pochylony krój pisma, który można podziwiać między innymi na banknotach serii „Władcy polscy”. Jest dość oryginalny, chociaż można w nim zauważyć wzorowanie się na antykwach renesansowych ${ }^{40}$. Charakteryzuje się lekkością i subtelnie zaznaczonymi szeryfami. Okolicznościowy charakter antykwy podkreśla sama jej nazwa będąca nawiązaniem do dystyngowanej królowej Bony ${ }^{41}$. Można powiedzieć, że grafik tworzył w duchu nowoczesnego projektowania, opracował bowiem krój kompleksowy z wieloma znakami specjalnymi i ligaturami ${ }^{42}$.

Andrzeja Heidricha wolno określić mianem człowieka renesansu. W swojej działalności graficznej nie ogranicza się bowiem do jednej dziedziny. Jest specjalistą zarówno od całościowego projektowania książek, jak i szeroko pojętej grafiki użytkowej, obejmującej ilustracje, kartki pocztowe, znaczki, banknoty, ekslibri-

${ }^{36}$ A. Szydłowska, M. Misiak, op. cit., s. 127.

37 Z.K. Jagodziński, Moi wielcy artyści - Czestaw Stania, Piotr Naszarkowski, Andrzej Heidrich, Warszawa 2009, s. 141.

38 Ibidem, s. 150.

${ }^{39}$ Ibidem, s. 150-151.

40 A. Frankowski, M. Frankowska, op. cit., s. 53.

${ }^{41}$ A. Szydłowska, M. Misiak, op. cit., s. 128.

42 A. Frankowski, M. Frankowska, op. cit., s. 53. 
sy i tak dalej. Za swoją twórczość został wyróżniony między innymi Złotym Medalem „Zasłużony Kulturze - Gloria Artis” (2006), a także Krzyżem Komandorskim Orderu Odrodzenia Polski (2014) „za wybitne osiągnięcia w pracy artystycznej, za zasługi dla rozwoju falerystyki, heraldyki i grafiki użytkowej”43.

\section{Andrzej Heidrich jako projektant książek}

Aby przekonać się, na czym polega harmonia i piękno projektów Andrzeja Heidricha, konieczna była dokładna analiza poszczególnych edycji w kontekście zasad typografii klasycznej. Kryterium wyboru publikacji stanowiło zajęcie jednego z głównych miejsc w Konkursie PTWK Najpiękniejsze Książki Roku, co pozwalało traktować je jako pozycje wzorcowe.

Spośród nich zdecydowanie wyróżnia się Witeź w tygrysiej skórze $e^{44}$ średniowieczny gruziński epos narodowy, którego autorem zgodnie z przyjętą tradycją jest Szota Rustaweli (III nagroda w kategorii literatura piękna w III edycji konkursu). Grafik podejmował tutaj eksperymenty związane ze sposobami rozpoczynania poszczególnych rozdziałów (Ilustracja 1).

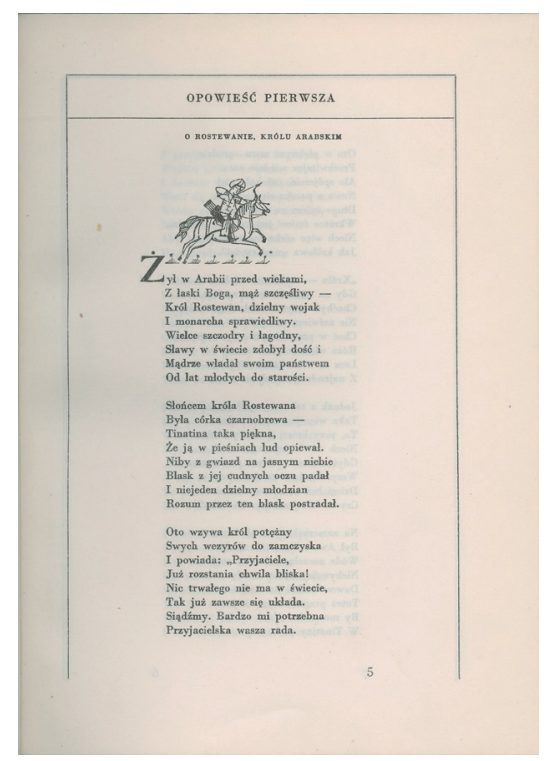

Ilustracja 1. Początek rozdziału z otoczonym ramką nagłówkiem, inicjałem i wkomponowaną w tekst ilustracją (S. Rustaweli, Witeź w tygrysiej skórze, Warszawa 1960)

Źródło: Zakład Narodowy im. Ossolińskich

${ }^{43}$ Postanowienie Prezydenta Rzeczypospolitej Polskiej z dnia 4 listopada 2014 r. o nadaniu orderów (M.P. 2015 poz. 53).

${ }^{44}$ Sz. Rustaweli, Witeź w tygrysiej skórze, Warszawa 1960. 
Zapisany słownie numer opowieści od góry i po bokach otacza ramka złożona z włosowych linii (nawiązująca do ramek stosowanych w edycjach XVI-wiecznych i późniejszych), a od dołu oddziela go od tekstu dodatkowa linia. Poniżej znajduje się wyśrodkowany ty tuł złożony wersalikami, i co ciekawe, wyróżniony mniejszym stopniem pisma od tekstu podstawowego, co jest niezwykle rzadkim zabiegiem. Można przypuszczać, że ma to na celu wprowadzenie dużej ilości światła. Tuż nad pierwszym wierszem każdej opowieści znajdują się czarno-białe ilustracje, idealnie wpasowujące się w kolumnę tekstu poematu. Są one dość uproszczone, przedstawiają na ogół postacie, zwierzęta, rośliny, budowle i różnego rodzaju przedmioty. Oprócz tych wszystkich wyróżnień grafik zastosował również ozdobne inicjały umieszczone na marginesie.

Jednym z najciekawszych pod względem edytorskim projektów Heidricha są Pamiętniki ${ }^{45}$ Giacomo Casanovy (I miejsce w kategorii literatura piękna, 1961 rok). Książka przykuwa uwagę świeżym spojrzeniem na projektowanie graficzne, przejawiającym się w niecodziennych rozwiązaniach typograficznych. Charakterystycznym elementem projektu jest tutaj kolumna szpicowa, nawiązująca do układu renesansowego (Ilustracja 2).

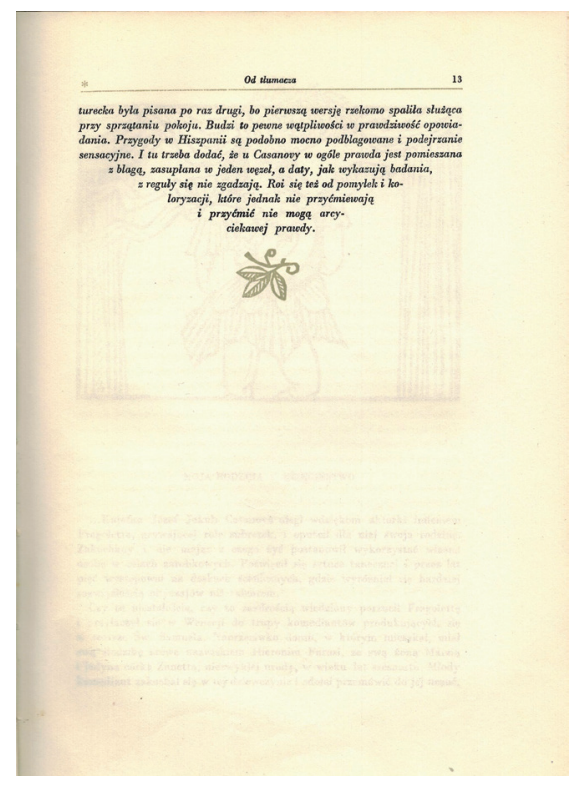

Ilustracja 2. Kolumna szpicowa (G.G. Casanova, Pamiętniki, Warszawa 1961)

Źródło: Zbiory własne.

Odznacza się tym, że początkowe wiersze są złożone na całą szerokość kolumny, natomiast kilka ostatnich jest stopniowo skracanych, a ponadto wyśrodkowanych i zakończonych elementem zdobniczym. Taka kolumna pojawia się w szczególnie

45 G.G. Casanova, Pamiętniki, Warszawa 1961. 
istotnych miejscach, wyróżniając materiały pochodzące od wydawcy lub tłumacza dzieła. Na największą uwagę zasługują jednak nagłówki (Ilustracja 3). Stosunkowo długie tytuły złożono w wyjustowane bloki. Nie rozciągają się one jednak na całą szerokość, ponieważ od strony zewnętrznej ograniczają je złote ilustracje autorstwa Heidricha, często umieszczone na spad. Materiał ilustracyjny przeważa nad nagłówkiem, bywa, że zajmuje nawet połowę strony. Takie nietypowe połączenie tekstu z grafiką na początku każdego rozdziału (a właściwie wpisu z pamiętnika) jest najpewniej głównym wyróżnikiem tej książki.

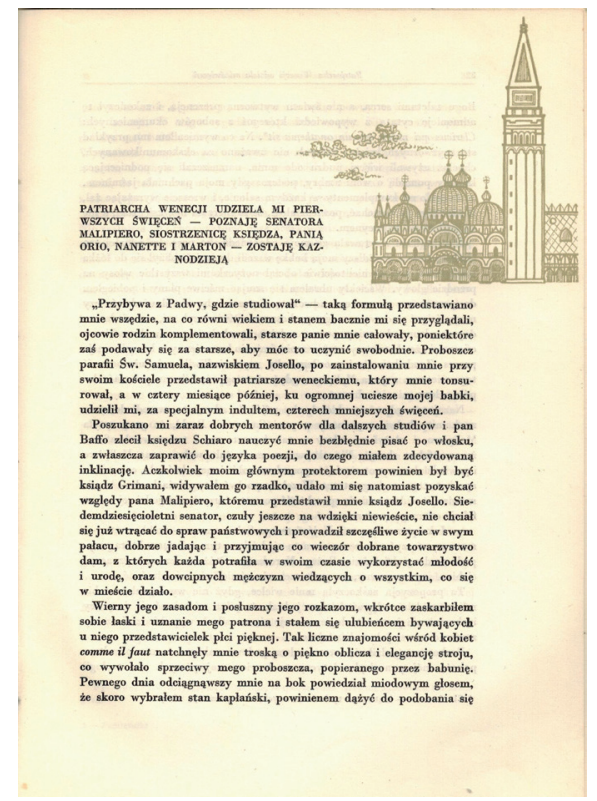

Ilustracja 3. Początek rozdziału — połączenie złotej ilustracji i blokowego nagłówka (G.G. Casanova, Pamiętniki, Warszawa 1961)

Źródło: Zbiory własne.

W tym samym roku nagrodę główną zdobyła równocześnie inna książka zaprojektowana przez Heidricha - Quo vadis ${ }^{46}$ Henryka Sienkiewicza. Interesujący jest tutaj sposób ukazania struktury tekstu (Ilustracja 4). Ciemnoczerwone, pogrubione numery rozdziałów umieszczono na zewnętrznym marginesie, w tej samej pionowej linii, co paginację. Początkowym stronom każdego z rozdziałów towarzyszą niewielkie ilustracje o wymiarach $5,5 \times 3 \mathrm{~cm}$. Obłamane tekstem ryciny są delikatnie wysunięte na zewnętrzny margines (niecały $1 \mathrm{~cm}$ ). Nie pojawiają się jednak bezpośrednio pod numerem rozdziału — od góry oblewane są przez trzy początkowe wiersze tekstu (rzadko dwa albo cztery, w zależności od długości pierwszego akapitu). Uproszczone, nieco schematyczne grafiki zostały stworzone w kolorach czerwonym i czarnym. Przedstawiają głównie postacie, budynki i zwierzęta.

${ }^{46}$ H. Sienkiewicz, Quo vadis, Warszawa 1961. 


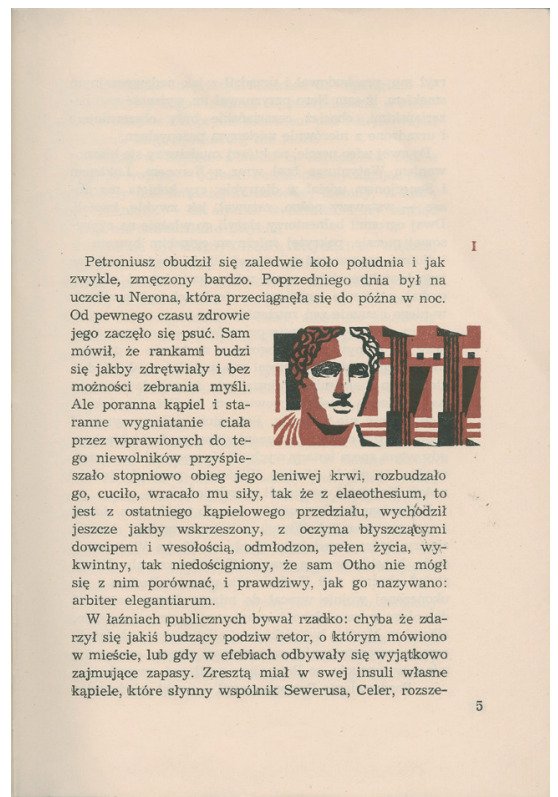

Ilustracja 4. Początek rozdziału z charakterystyczną czerwono-czarną ilustracją obłamaną tekstem (H. Sienkiewicz, Quo vadis, Warszawa 1961)

Źródło: Zakład Narodowy im. Ossolińskich.

Warto również zwrócić uwagę na inne nagrodzone edycje, takie jak zbiór opowiadań Jarosława Iwaszkiewicza Sny Ogrody Sérénité 47 będący klasycznym przykładem prostego, funkcjonalnego projektowania oraz publikacje albumowe, w tym Wilanów. Rezydencja Króla Zwycięzcy ${ }^{48}$, Nieborów Arkadia ${ }^{49}$ i Secesja w zbiorach polskich ${ }^{50}$. W tej grupie znalazły się także edycje o charakterze faksymilowym, na przykład Codex Aureus Gnesnensis ${ }^{51}$, czyli budzące podziw wydanie Ewangeliarza gnieźnieńskiego, czy tomik $Z$ wierszy ocalałych ${ }^{52}$ Juliusza Słowackiego.

Wśród najpiękniejszych książek nagrodzonych przez PTWK znalazły się również takie, w których wkład Andrzeja Heidricha ograniczał się tylko do zaprojektowania okładki i strony tytułowej lub ilustracji. Należy tu wymienić Anegdoty i sensacje obyczajowe wieku oświecenia w Polsce ${ }^{53}$ z gustowną oprawą i kartą tytułową Heidricha oraz wydanie Pana Tadeusza ${ }^{54}$ z 1963 roku z winie-

\footnotetext{
47 J. Iwaszkiewicz, Sny Ogrody Sérénité, Warszawa 1974.

48 W. Fijałkowski, Wilanów. Rezydencja Króla Zwycięzcy, Warszawa 1983.

${ }^{49}$ K. Jabłoński, W. Piwkowski, Nieborów Arkadia, Warszawa 1988.

50 P. Banaś, Secesja w zbiorach polskich, Warszawa 1990.

51 Codex Aureus Gnesnensis, Warszawa 1988.

52 J. Słowacki, Z wierszy ocalatych, Warszawa 1989.

53 Anegdoty i sensacje obyczajowe wieku oświecenia w Polsce. Dokumenty. Wspomnienia. Facecje, zebrał i oprac. R. Kaleta, il. M. Berezowska, Warszawa 1958.

54 A. Mickiewicz, Pan Tadeusz, Warszawa 1963.
} 
tami jego autorstwa, pojawiającymi się na początku każdej z dwunastu ksiąg poematu (są to niewielkie, czarno-białe rysunki przedstawiające bohaterów, miejsca i wydarzenia nawiązujące do tekstu).

Analiza typograficzna prac Andrzeja Heidricha wyraźnie ukazuje przywiązanie do klasycznych, sprawdzonych rozwiązań. W tekście głównym unikał groteski, za to $z$ umiłowaniem stosował kroje dwuelementowe szeryfowe na przykład Bodoni —znaną antykwę klasycystyczną zaprojektowaną przez włoskiego drukarza Giambattistę Bodoniego pod koniec XVIII wieku (użył jej między innymi w książkach Witeź w tygrysiej skórze i Pamiętniki). Czytelne, a zarazem eleganckie litery stanowiły budulec tekstu głównego. Heidrich nie próbował również eksperymentować z interlinią. Prawie wszędzie ma ona zgodną z normami wydawniczymi wielkość, uzależnioną od długości wiersza. Tekst jest więc czytelny i funkcjonalny.

W większości edycji dominuje klasyczna kolumna o linearnym układzie kompozycyjnym. Wielkość kolumny i marginesów w wielu projektach Heidricha nawiązuje do złotego podziału i proporcji odkrytych przez Jana Tschicholda w wyniku badań średniowiecznych rękopisów. Jednak można spotkać publikacje, w których grafik również na tym polu podejmował eksperymenty. Widać to szczególnie w wydawnictwach albumowych. W publikacji Nieborów Arkadia znacznie zwęził szerokość łamu na rzecz marginesu wewnętrznego, stanowiącego miejsce dla ilustracji i podpisów pod nimi. Z kolei w albumie Wilanów. Rezydencja króla zwycięzcy w zasadniczej części tekstu obowiązuje układ trójszpaltowy z ciekawym wykorzystaniem symetrii, polegającym na pozostawaniu środkowego łamu pustego. Pod tym względem wyróżniają się również Pamiętniki, w niektórych miejscach zastosowano wspomniany wcześniej renesansowy układ szpicowy zwieńczony ornamentem. Wśród edycji zaprojektowanych przez Heidricha pojawiają się (choć niezbyt często) takie, które mają niestandardowe marginesy (za duże, za małe lub całkiem nieproporcjonalne). Trudno stwierdzić, czy są one rezultatem jego koncepcji. Przypadki wydawania takich publikacji miały miejsce szczególnie w latach dziewięćdziesiątych, dlatego prawdopodobnie należałoby je wiązać z problemami, jakie napotkał w tym czasie polski przemysł poligraficzny. Kolejnym klasycznym elementem jest cyfrowa paginacja, która zawsze znajduje się $\mathrm{w}$ tradycyjnych miejscach, takich jak dolny margines (wyśrodkowana lub wyrównana do zewnętrznego marginesu). Zgodnie z zasadami złożona jest krojem tekstu głównego o tej samej wielkości bądź o stopień mniejszym. Również z powodu złego stanu polskiego drukarstwa w II połowie ubiegłego wieku, nie zawsze udawało się zachować registru w obrębie całej publikacji.

Należy tutaj także wspomnieć o sposobach ułatwiających percepcję tekstu, pomagających czytelnikowi odnaleźć się w strukturze tomu. Heidrich przede wszystkim szukał sposobów innych niż standardowe na rozpoczęcie rozdziałów. Oprócz kapitalików, wersalików czy większego stopnia pisma używał czasem ramek charakterystycznych dla starych druków, a nawet podkreśleń, które uznawane są wśród typografów za błąd. Jednak delikatne linie były poprowadzone umiejętnie, w sposób 
inny niż zwykłe podkreślenie. Heidrich eksperymentował niekiedy z rozmieszczaniem nagłówków na stronie. Niektóre rozwiązania były dość odważne, tak jak chociażby w wydaniu Pamiętników. Cechą charakterystyczną u Heidricha było wiązanie nagłówków z ilustracjami i winietami, co jeszcze bardziej uwydatniało strukturę tekstu. Często były to niewielkie, kolorowe grafiki na spad, oblewane tekstem. We wstępach używał tego samego rodzaju pisma, co w dalszych częściach książki, ale w odmianie pochylonej. W interesujący sposób wyróżniał cytaty — rezygnował $\mathrm{z}$ tradycyjnego cudzysłowu lub kursywy na rzecz mocniejszego wyodrębnienia, polegającego na zastosowaniu wcięcia akapitowego i zmniejszenia stopnia pisma. Heidrich przestrzegał tu zasady, która głosi, że wcięcie powinno być takiej wielkości, aby najdłuższy z cytowanych wierszy był wyśrodkowany ${ }^{55}$. Takiemu sposobowi wyróżniania towarzyszył często niewielki odstęp od tekstu głównego. Niekiedy, oprócz światła, cytaty były dodatkowo odseparowane wierszem złożonym z kropek — takie rozwiązanie zastosowano w wydaniu Quo vadis z 1961 roku.

W większości książek zaprojektowanych przez Heidricha ważną rolę odgrywał materiał ilustracyjny, którego sporadycznie był autorem. W początkowych latach kariery ilustrował w sposób dosłowny i opisowy. Natomiast na przełomie lat pięćdziesiątych i sześćdziesiątych zmienił swój styl, upraszczając rysunki i częściej wykorzystując metafory i podteksty ${ }^{56}$. Grafikę zawsze próbował łączyć z tekstem tak, aby zachować ich funkcjonalność i estetykę. Kluczową rolę ilustracje odgrywały w publikacjach albumowych. Przykładem są fotografie w książce Nieborów Arkadia, przedstawiające obiekty lub postacie opisywane w tekście i niejednokrotnie wzbogacone o rozbudowane podpisy. Często można spotkać ilustracje zdobnicze, które nie są bezpośrednio związane z tekstem głównym, ale nawiązują do niego swoim stylem. Można tu zaliczyć chociażby kolorowe wkładki w książce Witeź w tygrysiej skórze, będące reprodukcjami starogruzińskich miniatur. Istotnym elementem jest również stosowany z niezwykłym wyczuciem typograficzny materiał zdobniczy, taki jak ramki, linie, winiety czy inicjały.

Heidrich przywiązywał dużą wagę do stron tytułowych. Projektował je według klasycznego schematu z podziałem na górną, bardziej wyróżniającą się część (z tytułem i nazwiskiem autora) oraz dolną, mniej wyróżnioną, z nazwą wydawnictwa i datą wydania ${ }^{57}$. Strony tytułowe miały w większości klasyczny, wyśrodkowany układ — jako przykład odstępstwa od tej reguły mogą posłużyć Sny Ogrody Sérénité z nieregularnym układem blokowym. Heidrich starał się na nich operować jednocześnie słowem i obrazem. Grafika mogła być zastosowana jako tło całej strony albo ograniczona tylko do winiety, ramki czy mniej lub bardziej skromnego ornamentu. Często na stronie tytułowej stosował kroje kontrastowe w stosunku do tych zastosowanych w tekście głównym. Uwagę zwracają zaprojektowane przez Heidricha

55 T. Malinowska, L. Syta, Redagowanie techniczne ksiązki, Warszawa 1977, s. 86.

${ }^{56}$ Książki szlachetny ksztalt: wystawa prac Andrzeja Heidricha, czerwiec-lipiec 1981, Wrocław, oprac. T. Pieniążek, Wrocław 1981.

${ }^{57}$ T. Malinowska, L. Syta, op. cit., s. 142. 
strony tytułowe w publikacji Anegdoty i sensacje obyczajowe wieku oświecenia w Polsce, która wyróżnia się szczególnie estetycznym rozwiązaniem typograficznym. Heidrich wzbogacił dwuelementowy krój szeryfowy, którym złożono tytuł dzieła, w ozdobne wydłużone zakończenia liter, charakterystyczne dla pisma kaligraficznego, dzięki czemu karta tytułowa idealnie komponuje się z całostronicową ilustracją na stronie przytytułowej. Chociaż jego wkład ograniczył się tylko do zaprojektowania oprawy i karty tytułowej, można mieć pewność, że zasadniczo wpłynął na podwyższenie jakości estetycznej całej publikacji.

Częstym zabiegiem było również wyróżnianie tytułów lub podtytułów książek za pomocą koloru, przede wszystkim czerwonego, co można potraktować jako nawiązanie do książki średniowiecznej, a konkretnie — do czynności rubrykowania. Oprócz czerwieni kolorem, który chętnie wykorzystywał, był złoty, oznaczający w naszej kulturze bogactwo i atrybuty władzy królewskiej. Najwidoczniej Heidrich wziął pod uwagę tę symbolikę, ponieważ złoto pojawia się na przykład we wspomnianych wcześniej albumach poświęconych pałacom w Wilanowie i Nieborowie.

Heidrich był zwolennikiem umiaru i klarowności także w projektowaniu okładek. Niejednokrotnie nawiązywały one swoim wyglądem do stron tytułowych. Starał się na nich używać tych samych krojów pisma, elementów graficznych i kolorystyki. Rozpoznawalne są także inne okładki jego autorstwa, pominięte w konkursie PTWK. Przykładem mogą być te zaprojektowane dla książek Jarosława Iwaszkiewicza z charakterystyczną głową meduzy czy dla w serii wydawniczej „Nike” wydawnictwa Czytelnik, odznaczającej się przede wszystkim prostotą ${ }^{58}$. Ciekawie prezentują się także okładki do serii „Książek Poetyckich”, w których Heidrich tworzył abstrakcyjne kolorowe kompozycje z figur geometrycznych ${ }^{59}$. Grafik projektował także okładki książek dla dzieci, w których „bawił się” literą, pomysłowo łącząc tekst z rysunkiem, tak jak w zbiorze utworów Leszka Kołakowskiego 13 bajek z królestwa Lailonii dla dużych i małych ${ }^{60}$.

\section{Podsumowanie}

Na podstawie analizy typograficznej edycji można zauważyć, że twórczość Andrzeja Heidricha charakteryzują liczne nawiązania do klasycznych rozwiązań stosowanych przez dawnych mistrzów sztuki drukarskiej. Jednak nie wykorzystywał ich na zasadzie wiernego odwzorowywania. Starał się raczej unowocześnić

\footnotetext{
58 A. Frankowski, M. Frankowska, op. cit., s. 46-49.

59 Ibidem, s. 49.

${ }^{60}$ L. Kołakowski, 13 bajek z królestwa Lailonii dla dużych i małych, Warszawa 1966.
} 
pewne elementy, zaprojektować je według własnej koncepcji poprzez wprowadzenie większej ilości rozwiązań kontrastowych, dynamicznych. Może nie zawsze były to eksperymenty rewolucyjne, ale z pewnością przyczyniły się do podniesienia poziomu edytorskiego książek.

Jego podejście do projektowania idealnie podsumowała Danuta Wróblewska w artykule Litera, znak, książka z 1980 roku:

Można powiedzieć, że stoi po stronie klasyków, jeśli pod tym słowem zgodzimy się rozumieć zwolenników umiaru i klarowności. Rozumie książkę jako rzecz maksymalnie użytkową, jest przywiązany do tradycji kodeksu. Ważne są dla niego wizualne właściwości przedmiotu książki, jej materialność, ale i jej duch. Lecz Heidrich jest klasykiem nieortodoksyjnym, nie przesadza więc z rygorem, i znając we wszystkich czasoprzestrzennych wymiarach strukturę książki, wie do jakiego stopnia jest ona elastyczna. Aprobuje więc tradycyjną jednorodność treści z formą, forując wszakże młode pomysły, nawet bardzo nieokiełznane ${ }^{61}$.

\section{Bibliografia}

\section{Źródła}

Anegdoty i sensacje obyczajowe wieku oświecenia w Polsce. Dokumenty. Wspomnienia. Facecje, zebrał i oprac. R. Kaleta, il. M. Berezowska, Warszawa 1958.

Banaś P., Secesja w zbiorach polskich, Warszawa 1990.

Casanova G.G., Pamiętniki, Warszawa 1961.

Codex Aureus Gnesnensis, Warszawa 1988.

Fijałkowski W., Wilanów. Rezydencja Króla Zwycięzcy, Warszawa 1983.

Iwanicka K., Artyści polskiej ksiązki. 50 lat Konkursu PTWK, Warszawa 2009.

Iwaszkiewicz J., Sny Ogrody Sérénité, Warszawa 1974.

Jabłoński K., Piwkowski W., Nieborów Arkadia, Warszawa 1988.

Kołakowski L., 13 bajek z królestwa Lailonii dla dużych i małych, Warszawa 1966.

Mickiewicz A., Pan Tadeusz, Warszawa 1963.

Najpiękniejsze książki. 40 Konkursów Polskiego Towarzystwa Wydawców Książek 1957-1999, Warszawa 2000.

Postanowienie Prezydenta Rzeczypospolitej Polskiej z dnia 4 listopada 2014 r. o nadaniu orderów (M.P. 2015 poz. 53).

Rustaweli Sz., Witeź w tygrysiej skórze, Warszawa 1960.

Sienkiewicz H., Quo vadis, Warszawa 1961.

Słowacki J., Z wierszy ocalatych, Warszawa 1989.

${ }^{61}$ D. Wróblewska, Litera, znak, książka, „Projekt” 1980, nr 6, s. 53-54. 


\section{Opracowania}

Andrzej Heidrich. Malarz polskich banknotów, http://www.muzeum.miejskie.wroclaw.pl/CMS/muzeum_historyczne/heidrich.html [dostęp: 23.04.2016].

Andrzej Heidrich — twórca polskich banknotów, Warszawa 2011, http://www.nbp.pl/AndrzejHeidrich/e-book/files/assets/downloads/files/AndrzejHeidrich.pdf [dostęp: 23.04 2016].

Chamera-Nowak A., Problemy złej jakości wykonania książek w latach pięćdziesiatych XX wieku w Polsce: stalinowskie diagnozy, rzeczywiste przyczyny, „Z Badań nad Książką i Księgozbiorami Historycznymi" 2013, t. 7-8.

Cztery Konkursy na Najlepiej Wydana Książę w latach 1957-1961, oprac. R. Tomaszewski, Warszawa 1964.

Fangor W. et al., Jak ktoś mógł na to pozwolić! Z twórcami polskiej szkoły grafiki rozmawia Janusz Górski, Warszawa 2011.

Frankowski A., Frankowska M., Dyskretna Perfekcja, „2+3D”2011, nr 2.

Heidrich A., Sztuka proporcji, [w:] Lucem dabit atra fuligo. Światlo dała czarna sadza. Leon Urbański (1926-1998), Warszawa 2007.

Jagodziński Z.K., Moi wielcy artyści - Czesław Stania, Piotr Naszarkowski, Andrzej Heidrich, Warszawa 2009.

Jak ktoś mógł na to pozwolić! Z twórcami polskiej szkoły grafiki rozmawia Janusz Górski, red. P. Sitkiewicz, Warszawa 2011.

Ksiązki szlachetny kształt: wystawa prac Andrzeja Heidricha, czerwiec-lipiec 1981, Wrocław, oprac. T. Pieniążek, Wrocław 1981.

Malinowska T., Syta L., Redagowanie techniczne książi, Warszawa 1977.

Mrowczyk J., Warda M., PGR: Projektowanie graficzne w Polsce, Kraków 2010.

Newark Q., Design i grafika dzisiaj. Podręcznik grafiki użtkowej, Warszawa 2006.

Regulamin konkursu Polskiego Towarzystwa Wydawców Książek „Najpiękniejsze Książki Roku”, http://www.ptwk.pl/images/pdf/2017/Regulamin_NKR.pdf [dostęp: 27.06.2017].

Repucho E., Od sztuki pięknego składu do narzędzia komunikacji wizualnej. Przemiany pojęcia typografii na przestrzeni XX i poczatków XXI wieku, „Acta Poligraphica” 2016, nr 8, s. 85-97.

Skierkowska E., Wspótczesna ilustracja książki, Wrocław 1969.

Szydłowska A., Misiak M., Paneuropa, Kometa, Hel: szkice z historii projektowania liter w Polsce, Kraków 2015.

Szymczyk M., Polski przemyst papierniczy 1945-1989, Duszniki Zdrój 2007.

Wincencjusz-Patyna A., U źródet światowych sukcesów Polskiej Szkoły Ilustracji, „Quart. Kwartalnik Instytutu Historii Sztuki Uniwersytetu Wrocławskiego" 2009, nr 1.

Wróblewska D., Litera, znak, książka, „Projekt” 1980, nr 6.

\section{An unorthodox classic. The esthetics of a book in Andrzej Heidrich's works}

Summary

Graphic design in Poland after World War II has not been completely explored so far. This article describes the state of graphic design during the Polish People's Republic period as well as presents the life and work of Andrzej Heidrich - one of the leading designers of that time. It shows his artistic versatility, which manifests itself in designing such varied works as books, banknotes, bookplates, 
postage stamps, identity papers and more. The main purpose of this article is to present one of Heidrich's work aspects - the book design. The conclusions show that Heidrich is the advocate of classic solutions, developed by former printing masters. However, he attempts to modify some elements, making them modern and original.

KEYWORDS: Andrzej Heidrich, Polish graphic design, book design, typography 